\section{References}

Baimliranov, A. 1989. Two humped camels, in N.G. Dmitriev \& L.K. Ernst (ed.), Animal genetic resources of the USSR. Rome: FAO. Animal Production and Health Paper 65: 346-351.

$B \wedge R$ rosiewiCz, L. 1995. Camel remains from Hungary, in $\mathrm{H}$. Buitenhuis \& H.-P. Uexpmann (ed.), Archaeozoology of the Near East II: 119-25. Leiden: Backhuys.

1996. Camels in antiquity: the Hungarian connection, Antiquity 70: 447-53.

1999a. Recent developments in archaeozoological research in Slovenia, Arheološki vestnik 50:285-95.

1999b. A lelốhely állatcsontanyaga - archaeozoológia [Animal bones from the site - archaeozoology], in T. Petercsák \& J.J. Szabó (ed.), Kompolt-Kistér: 279-338. Eger: Heves Megyei Régészeti Közlemények.

BENECKE, N. 1994. Der Mensch und seine Haustiere. Die Geschichte einer jahrtausendealten Beziehung. Stuttgart: Konrad Theiss Verlag.

BERGER, M. \& E. THENIUS. 1951. Üher römerzeitliche Kamelfunde in Stadtgebiet von Wien, Veröffentlichungen des Historischen Museums der Stadt Wien: 20-22

BoEssneck, J. 1964. Die Tierknochen aus den Grabungen 19541957 auf dem Lorenzberg bei Epfach, in J. Werner (ed.), Studien zu Abodiacum-Epfach: 213-61. Munich: C.H. Beck'sche Verlagsbuchhandlung.

BÖKÖNYI, S. 1974. History of domestic mammals in Central and Eastern Europe. Budapest: Akadémiai Kiadó.

1984. Animal husbandry and hunting in Tác-Gorsium. The vertebrate fauna of a Roman town in Pannonia. Budapest: Akadémiai Kiadó

1989. Camel sacrifice in Roman Intercisa, Acta Archaeologica Academiae Scientiarum Hungaricae 61(1-4): 399-404.

DRIESCH, A. VON DEN. 1976. Das Vermessen von Tierknochen aus vor- und frühgeschichtliche Siedlungen. Dissertation, Institut für Paläoanatomie, Domestikationsforschung und Geschichte der Tiermedizin der Universität München.

GIESLER, U. 1981. Kleinfunde, in Ulbert (ed.): 53-102.

KÖHLER-ROLLEFSON, I. 1989. Zoological analysis of camel skeletons, in R.H. Smith \& L.P. Day (ed.), Pella of the Decapolis 2: 142-53. Wooster (OH): College of Wooster.

KRÄMER, H. 1899. Die Haustierfunde von Vindonissa, Revue Suisse de Zoologie 7: 143-272.
LESBRE, M.F.X. 1903. Recherches anatomiques sur les Camélidés, Archives d'Histoire Naturelle de Lyon 8: 1-195.

MASHKOUR, M. 1997. The funeral rites at Mleiha (Sharja-U.A.E.); the Camelid graves, Anthropozoologica 25-26: 725-36.

MAson, I.L. 1984. Camels, in I.L. Mason (ed.), Evolution of domesticated animals: 106-15. London: Longman.

MEZHLUMIAN, S.K. 1988. Домшний верблюд (CAMELUS DROMEDARIUS L.) из прибрежных отложений озера Севан, Биологический жсурнал Армении 41/8: 661-8.

MORALES MUŇIZ, A., J. A. RIQUELME \& C. LIESAUU VON LETTOWVORBECK, 1995. Dromedaries in antiquity: Iberia and beyond, Antiquity 69: 368-75.

PIEHler, W. 1976. Die Knochenfunde aus dem spätrömischen Kastell Vemania. Dissertation, München, Institut für Paläoanatomie, Domestikationsforschung und Geschichte der Tiermedizin der Universität München.

RIEDEL, A. 1999. Kamelfunde der frühen römischen Käiserzeit aus Mauerbach (Niederösterreich, Bezirk WienUmgebung), Annalen des Naturhistorischen Museums, Wien 100A: 81-92.

SCHMidT-P $\Lambda$ ULY, S, 1980. Römerzeitliche und mittelalterliche Tierknochenfunde aus Breisach, im Breisgau. Dissertation München, Institut für Paläoanatomie, Domestikationsforschung und Geschichte der Tiermedizin der Universität München.

STEIGER, C. 1990. Vergleichend morphologische Untersuchungen an Einzelknochen des postkranialen Skeletts der Altweltkamele. Dissertation. Institut für Paläoanatomie. Domestikationsforschung und Geschichte der Tiermedizin der Universität München.

UERPMANN, H.-P. 1999. Camel and horse skeletons from protohistoric graves at Mleiha in the Emirate of Sharjah (U.A.E.). Arabian archoeology and epigraphy 10: 102-18.

2000. The identification of camel hybrids. Paper delivered at the 5th international Conference of Archaeozoology of Southwest Asia and Adjacent Areas, Yarmouk University, Irbid, Jordan, 2-5 April 2000.

Ulber'T, T. 1981. Ad Pirum (Hrušica). Spätrömische Passbefestigung in den Julischen Alpen. Der deutsche Beitrag zu den slowenisch-deutschen Crabungen 1971-1973. C.H. Beck'sche Verlagsbuchhandlung. Münchner Beiträge zur Vor- und Frühgeschichte, Band 31

\title{
Were the Scots Irish?
}

\section{EWAN CAMPBELL *}

The author attributes the claimed migrations of the Irish into Argyll to a set of élite origin myths, finding no support in archaeological evidence. He goes on to ask how the Iron Age populations of Argyll established and changed their personal and group identity.

Key-words: origin myths, migration, Scots, Irish, Argyll

The traditional historical account of the origin of the Scottish kingdom states that the Scots founded the early kingdom of Dál Riata in western Scotland in the early 6th century, having migrated there from northeastern Antrim, Ireland. In the process they displaced a native Pictish or British people from an area roughly equivalent to the modern county of Argyll. Later,

* Department of Archaeology, University of Glasgow, Glasgow G12 8QQ, Scotland.

Received 13 November 2000, 12 December 2000, accepted 26 January 2001

ANTIQUTTY 75 (2001): 285-92 
in the mid 9th century, these Scots of Dál Riata took over the Pictish kingdorn of eastern Scotland to form the united kingdom of $A l b a$, later to become known as Scotland. To the classical authors of late antiquity, the peoples of Ireland were Scotti, probably a derogatory term meaning something like 'pirates'. The name was used by early medieval writers in Latin for all speakers of Gaelic, whether in Ireland or Scotland. Much later the usage became associated exclusively with the peoples of Scotland, whether speakers of Gaelic or not. In this paper I will use the term Goidelic for the Irish/Scottish Gaelic branch of Celtic (Q-Celtic), and Brittonic for the British group including Welsh, Pictish and Cumbric (P-Celtic).

After a period of virulent sectarian debate on the origins of the Scots in the 18th and 19th centuries (Ferguson 1998), the idea of a migration of the Scots to Argyll has become fixed as a fact in both the popular and academic mind for at least a century. Present-day archaeological textbooks show a wave of invasive black arrows attacking the west coast of Britain from Ireland in the late 4 th $/ 5$ th centuries (e.g. Laing 1975: figure 1). Even the tide of anti-migrationism as explanation for culture change which swept through British prehistory in the 1970s and washed into Anglo-Saxon studies in the $1980 \mathrm{~s}$ left this concept remarkably intact. Irish historians still regularly speak of the 'Irish colonies in Britain' (ó Cróinín 1995: 18; Byrne 1973: 9 ), and British anti-invasionist prehistorians seem happy to accept the concept (e.g. Cunliffe 1979: 163, figure). The insistence on an explicitly colonialist terminology is somewhat ironic given the past reaction of many Irish archaeologists to what they perceived as intellectual cryptocolonialism of British archaeologists and art historians over the origin of the Insular illustrated manuscripts and items such as hanging bowls. Exactly why colonialist explanations should have survived in the 'Celtic West' while being hotly debated in eastern Britain is of considerable interest, but not the purpose of this paper, which is to provide a critical examination of the archaeological, historical and linguistic evidence for a Scottic migration, and provide a new explanation for the origins of Dál Riata.

There had never been any serious archaeological justification for the supposed Scottic migration. Leslie Alcock is one of the few to have looked at the archaeological evidence in detail, coming to the conclusion that 'The settlements show very little sign of the transplantation of material culture to Dalriadic Scotland or to Dyfed' (Alcock 1970: 65). This lack of archaeological evidence has led some younger archaeologists to adopt a more cautious approach, suggesting that perhaps there was an élite takeover of the local ruling dynasty, rather than a mass migration of peoples, and that contact may have taken place over a longer timescale than the conventional view (Foster 1996: 13-14). The paradigm of Irish migration remains strong however, bolstered by the evidence from other areas of western Britain. During the expansion of interest in 'Dark Age Britain', scholars familiar with the historical and genealogical accounts of Irish origins of some western kingdoms, explicitly searched for, and believed they had found, archaeological evidence for these migrations. Examples can be quoted for ogham stones in Dyfed, Brecon, Gwynedd and Dumnonia (Macalister 1949); placenames in Dyfed (Richards 1960), Galloway (Nicolaisen 1976) and Cornwall (Thomas 1973); settlement forms in Somerset (Rahtz 1976); and pottery in Cornwall (Thomas 1968). This illustrates that there was a climate amongst scholars working in this area who saw cultural explanations in terms of an historical/linguistic paradigm which they applied to all areas of western Britain.

\section{Archaeological evidence}

If there had been any substantial movement of people into Argyll, there should be some sign of this in the archaeological record, even though few would now accept a simplistic equation of material culture and population groups. One reason why no evidence has been brought forward in the past is the relative lack of archaeological investigation in Argyll, and also in Antrim. However, since Alcock produced his 1970 paper there has been substantial progress in understanding early medieval Argyll, giving us the opportunity to re-examine the archaeological evidence. The areas of material culture where we might expect to see signs of incomers from a different cultural group are personal jewellery such as brooches and pins, and settlement forms. Both areas were aceramic at this period.

The characteristic settlement forms in Ireland are circular enclosures with earthen banks 
(raths) or stone walls (cashels), and artificial island dwellings (crannogs). Crannogs are found in Argyll, but unfortunately for proponents of an Irish origin for crannogs, dendrochronological dating has shown that Scottish crannogs have been constructed since the early Iron Age (Barber \& Crone 1993), while Irish ones almost all date from after AD 600 (Baillie 1985; Lynn 1983), suggesting if anything an influence from Scotland to Ireland. Although recent work has suggested some Irish crannogs may be earlier than this, and that some Scottish crannogs may share some constructional features with Irish ones (Crone 2000), this does no more than suggest a shared cultural milieu which may have lasted over a very long period and covered most of Scotland and Ireland.

The raths and cashels of Ireland are the characteristic early medieval settlement form, with over 30,000 recorded (Stout 1997). None, however, are known from Argyll. The characteristic settlement form in Argyll is the hilltop dun, a sub-circular stone walled roofed enclosure with features such as internal wall-stairs and intra-mural chambers (RCAHMS 1988: 31). Radiocarbon dates show that these have been built since the early iron age through to the late 1st millennium $\mathrm{AD}$, and form a coherent area of distinctive settlement type in Argyll in contrast to the brochs, enclosures and forts of other areas of Scotland (Henderson 2000: figure 1). There is therefore no evidence of a change in the normal settlement type at any point in the 1st millennium $\mathrm{AD}$ and no basis for suggesting any significant population movement between Antrim and Argyll in the 1st millennium AD. At best, the evidence shows a shared cultural region from the Iron Age, with some subsequent divergence in the later 1st millennium AD. Any cultural influences could be argued as likely to have been going from Scotland to Ireland rather than vice versa.

If there was no major movement of people, perhaps there was an élite takeover, similar to the Norman invasion of England. The lack of change in domestic equipment and settlement form could then be explained by the adoption of local cultural traditions. One might expect, however, that such an élite would differentiate themselves in some way in terms of their group identity. At this period there is good evidence that one way in which this was done was through the use of distinctive personal jew- ellery, particularly brooches (Nieke 1993), and most royal sites of the period have produced evidence of manufacture of silver and gold brooches (Campbell 1996). The distributions of different forms of early medieval brooches and pins show strong regional patterns, and though these may not coincide with political or ethnic boundaries, they do suggest a relationship with some form of group identity. Rather strangely, these distributions do not appear to have been studied in relation to the migration theory.

The main form of brooch in 4th-6th-century Ireland is the zoomorphic penannular brooch (Kilbride-Jones 1980). The typological development and dating of these brooches has been controversial, but has been recently elucidated by Raghnal Ó Flóinn (forthcoming). The form developed in the late 4th century in western Britain in the Severn Valley, but quickly spread to eastern Ireland where new forms were developed. These brooches are widely distributed in Ireland, but not one has been found in $\mathrm{Ar}$ gyll. The situation is similar with dress-pins, as one of the commonest types with over 40 examples in Ireland, the spiral-ringed ringheaded pin, was particularly common in the north (Campbell 1999: 14, figure), but only one is known in Argyll. Conversely, the commonest type of brooch in western British areas was the Type $\mathrm{G}$ penannular. Again the typology and chronology has been much debated, but a general development from a sub-Roman form (G1) in southwest Britain was followed by later types (G2 and G3) in northwestern areas. A workshop for Type G3 was found at Dunadd in Dál Riata (Lane \& Campbell 2000) and other Type G3 production sites have been found in Ireland, at Dooey, Donegal and Moynagh Lough, Meath. Are we here at last seeing evidence of a distinctive cultural feature moving from Ireland to Argyll? Unfortunately not, as the Scottish examples date to the early and mid 7 th century, while the Moynagh Lough metalworking phase is dated by dendrochronology to the early 8th century (Bradley 1993). Again, any cultural influence would appear to be in the opposite direction.

Thus there is no evidence in the archaeological record for any population movement from Ireland to Scotland, other than travel by occasional individuals. In Anglo-Saxon England we have an archaeologically invisible native 
British population, and debate centres on the extent to which they adopted the cultural package of Anglo-Saxons. In Argyll in contrast, it is the Goidelic invaders who are archaeologically invisible.

\section{Historical evidence}

The documentary sources for the migration of the Scotti are of varying date and validity but, as with the archaeological evidence, have not received full critical assessment by historians. The clearest expression is in the Irish chronicles, a source which has the best potential for containing contemporary records of early medieval events. In the Annals of Tighernach, an entry for around $\mathrm{AD} 500$ reads, 'Feargus mor mac earca cum gente dalriada partem britania tenuit et ibi mortus est' - 'Fergus Mor, mac Erc, with the nation of Dál Riada, took (or held) part of Britain, and died there'. This clear statement of invasion and colonization is, however, not a contemporary record, as is shown by the form of the Irish words. Dalriada, Feargus and Earca are Middle Irish forms where one would expect the Old Irish Dalriata, Fergus and Erca. These spellings show that the entry could not have been written before the 10th century. It has been strongly argued that this entry, which is the earliest independent record of Fergus, is one of a series of insertions in the Annals derived from a 10th-century 'Chronicle of Clonmacnoise' (Dumville 1993: 187; Grabowski \& Dumville 1984) and cannot be taken as independent evidence of colonization.

The other main source is the Senchus Fer nAlban (History of the Men of Scotland). This very important document is a social survey and genealogy of the kings of Dál Riata, believed to have been originally written in the later 7 th century and modified in the 10th century (Bannerman 1974). Even accepting the supposedly 10th-century version of the text uncritically, it does not refer to settlement but is a genealogical statement of the origins of the Scottish kings: 'Erc, moreover had twelve sons i. six of them took possession of Alba.' (Bannerman 1974: 47 ), and there follows a genealogy of the Dalriadan kings from Fergus Mor to the mid 7 th century. It is important to note that nowhere is a mass movement of peoples mentioned, it is purely an aristocratic, and specifically royal, takeover of Scotland. However, this account also cannot be a contemporary record, and can be shown to be part of the 10 th century or later rewriting of the original text (Bannerman 1974: 130-32), as AIba was not used as a term for Scotland before the 10 th century.

The other early source relating to the origins of Dál Riata is found in Bede's history of the English church, written in the early 8th century. Bede's account differs from that of the Senchus. After describing the wanderings of the Britons and Picts, he says that Britain 'received a third tribe, . . . namely the Irish. These came from Ireland under their leader Reuda, and won lands from the Picts... they are still called Dalreudini after this leader' (Colgrave \& Mynors 1969: 18-19). To summarize the historical sources, it appears that there are two conflicting accounts of the Irish origins of Scottish Dalriada. The first, exemplified by the Senchus and the Annals of Tigernach entry, belongs to no earlier than the 10th century, while an earlier tradition represented by Bede dates back to at least the 8th century. Bannerman has highlighted the difference between the two traditions, and suggests that an older tradition, reported by Bede, was supplanted in the 10th century by the Fergus Mor story for political purposes of the time (Bannerman 1974: 132).

These sources, and some other later material, are clearly origin legends of a type common to most peoples of the period, constructed to show the descent of a ruling dynasty from a powerful, mythical or religious figure. Such genealogies, could be, and often were, manipulated to suit the political climate of the times, as shown by the replacement of Carpre Riata by Fergus Mor. The genealogies cannot be taken as indications of past population movements, or even kinship ties. Recent research has highlighted how Middle Irish historians were promulgating a view of Irish kingship which had a considerable effect on Scottish politics from the 10 th to the 13th centuries. Herbert (2000) has shown how the Irish view of kingship, and political marriages, were influencing Scottish kings in the 10th century towards the concept of kingship of a land $(A I b a)$ rather than a people (the Dál Riata), and Duffy (2000) has demonstrated that there was Irish support for one line of rival claimants to the Scottish throne in the 11th century. This influence continued in the 12th-13th centuries (Broun 1999). It is probable that in this climate that the manipulation of the genealogies took place, with each line- 
age trying to outdo each other in stressing their antiquity and Irish origins. The earlier version of the legend was possibly constructed to bolster Dál Riata claims to territory in Antrim.

The critique of the sources presented above is not particularly new - each of the elements has been noted in the past, if not discussed in detail, but this has not led historians to question the invasion hypothesis. For example, in a recent paper David Dumville, an eminent historian and himself a noted deconstructer of early medieval myths, dismisses both the Fergus story and Bede's account, while in the same paragraph accepting the migration of settlers (Dumville 1993: 187). The absence of a critical appraisal of the migration story may be due to an easy acceptance by historians of the invasion paradigm. History has been largely unaffected by the anti-migration backlash which affected archaeology, not least because medieval historians work in a period when there are many indisputable invasions, although also due to a rejection of post-modernist approaches (e.g. Evans 1999). As far as Argyll is concerned, although few historians would now take the Fergus Mor story at face value, the linguistic evidence seems so clear that there is readiness to accept the concept of an Irish invasion or takeover, even if the actual details are uncertain and unsupported by the evidence.

\section{Linguistic evidence}

Linguistic evidence thus seems to provide the securest evidence for invasion by Gaels, and as we have seen, seems to have influenced historians and archaeologists to accept the theory even though they themselves have little evidence to support it. The presence of Gaelic speakers in early medieval Argyll is undoubted. Adomnán, writing in Argyll in the late 7th century, inhabits an entirely Gaelic world: all the placenames and personal names referred to in Argyll are Gaelic; the people of Argyll are "the Scotti in Britain', and he comments that Columba needed translators when he travelled to Pictish areas (Sharpe 1995: 32). In addition, the modern placenames of Argyll are all of Goidelic origin, in contrast to eastern Scotland where there is a substantial Brittonic substratum, even if many were adopted by later Gaelic speakers (Nicholaisen 1976; Taylor 1994). Yet Pictish was replaced by Gaelic as the language of eastern Scotland only a few hundred years after
Adomnán, so we would expect to see some Brittonic substratum in the placenames of Argyll. The traditional explanation is that original Brittonic speakers were totally displaced by Gaelic speaking settlers, removing all evidence of Brittonic settlement and landscape names. Such a complete obliteration without substantial population movement, which, as we have seen, is archaeologically invisible, would be almost unparalleled in onomastic history.

What is the evidence for this, other than the historical accounts of an invasion from Ireland? The only evidence for the language spoken in Argyll before the early medieval period is Ptolemy's Geography written in the early 2nd century. This locates the tribe of the Epidii, and a peninsula called Epidion Akron, on the west coast of Scotland, in an area generally equated with Kintyre (Rivet \& Smith 1979: 360-61). Epidii is P-Celtic, and therefore by implication this area was inhabited by Brittonic speakers. Apart from the dangers of relying on a single word to support a hypothesis of an entire language, there are good reasons for questioning this evidence. Ptolemy's source for his Scottish names was probably from the Scottish Central Lowlands, and may have transmitted the Brittonic form of a Goidelic tribal name, or even the external name given to the tribe by Brittonic speakers. Before the rapid divergence of Goidelic and Brittonic in the centuries around the collapse of the Roman Empire there may have been a much less homogenous pattern of language than we assume for the later periods. In support of this it is interesting that the PCeltic tribal name Menapii appears in Ptolemy's list of tribes in Ireland itself, and that several peoples of northern Ireland were known as Cruithin, Goidelic for 'British', but these peoples are accepted as being Goidelic speakers, and no 'British invasion' of Ireland is now postulated on the basis of this evidence (Toner 2000: 73). The only reason the name Epidii is used as evidence for invasion is that it appeared to support the historical evidence, which we have seen is unreliable. The traditional view seems inherently unlikely, based as it is on the evidence of a single word, and a simpler model is proposed below.

While no-one disputes that a divergence between Goidelic and Brittonic took place, and that Goidelic retains the most archaic features 


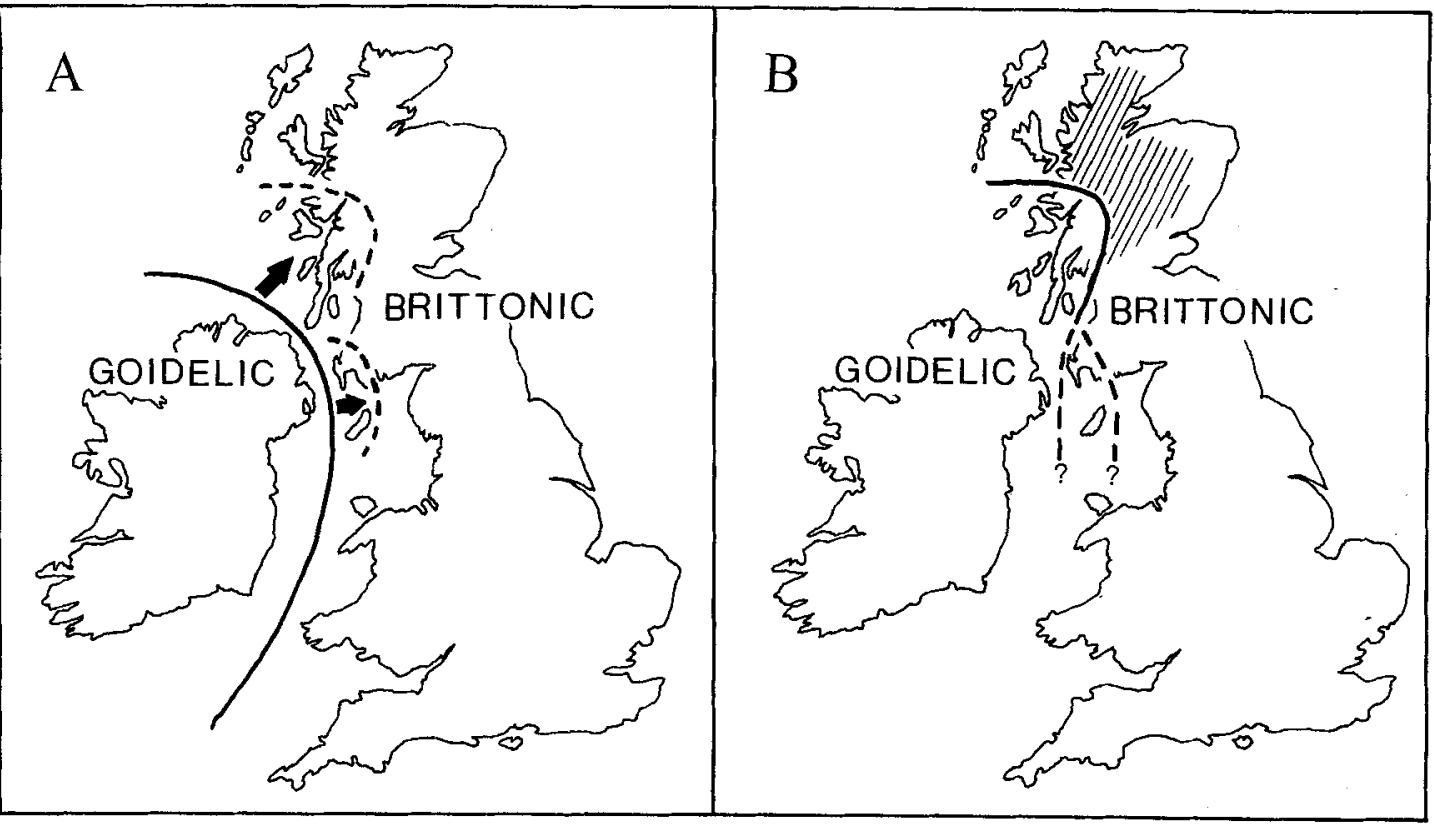

FIGURE 1. Two differing views of the fault-line between Goidelic and Brittonic. A Traditional view of the sea as the initial dividing mechanism, with subsequent spread of Goidelic eastwards. B Alternative view with the Scottish Highlands as the original dividing line between the languages.

of the Celtic language group, the question is where the original 'fault-line' between the two is to be placed. In their interpretation, linguists have tended to be guided by the historical paradigm in their explanations of language change in western Britain (FIGURE 1A). More subtly, I believe they have been affected by a geographical viewpoint which is based on a modern perceptions of communications and polities which sees 'Scotland' and 'Ireland' as independent geographical units. Thus, the Irish Sea and North Channel have come to be seen as the dividing line between Gael and Briton, only to be crossed by invasion. This view was not shared by early medieval commentators, who saw the dividing line as Druim Albin, the 'Spine of Britain' (the Grampian Highlands) being the linguistic barrier. It should not surprise us that the Highlands were a communications barrier. There are only two or three narrow routeways through the Highland massif, each involving several days travel on foot. It is easy to see how linguistic differentiation could take place when the peoples on either side of this barrier were only in sporadic communication. On the west coast however, most of Argyll is no more than a day's sail from Ireland, and at closest the distance between Argyll and Ireland is only 20 kilometres. There is abundant evidence to show that early medieval Argyll was a sea-based society (Bannerman 1974; Campbell 1999). In this context the North Channel can be seen as a linking mechanism rather than the dividing one envisaged in the concept of the 'sea-divided Gael' (O'Rahilly 1932: 123). The islands of Rathlin and Tiree are respectively $20 \mathrm{~km}$ and $100 \mathrm{~km}$ from mainland Argyll, though Rathlin is today officially in Ireland, and Tiree in Scotland. Both are clearly part of one archipelago where good sea communications would enable the same language to continue to be spoken and develop in tandem. Further south, the much wider Irish Sea would have made daily communication more difficult, and the 'fault line' could have lain between Ireland and mainland England and Wales (FIGURE 1B).

\section{An alternative view}

To summarize, if there was a mass migration from Ireland to Scotland, there should be some sign of this in the archaeological record, but there is none. If there was only an élite takeover by a warband, who must have adopted local material culture and settlement forms, there 
should be signs of the language of the native majority in the placenames, but again there is none. A purely dynastic takeover would not have led to language change on the scale seen, and has no clear historical backing. My reading of the archaeological, historical and linguistic evidence is radically different from the traditional account, but much simpler.

I suggest that the people inhabiting Argyll maintained a regional identity from at least the Iron Age through to the medieval period and that throughout this period they were Gaelic speakers. In this maritime province, sea communications dominated, and allowed a shared archaic language to be maintained, isolated from the linguistic developments which were taking place in the areas of Britain to the east of the Highland massif in the Late Roman period. Occasional developments in material culture and settlement types could pass from one area of the west to another, and of course individuals moved between the areas, but this was not on a sufficient scale to produce an homogenous cultural province. By the early medieval period, the emphasis on marine transport in Argyll allowed the development of a formidable navy, capable of maintaining a strong political identity within Argyll, and allowing Dál Riata to become an expansionist force in the area attacking as far away as Orkney, the Isle of Man and the west coast of Ireland (Campbell 1999: 53 , figure). For a time during this early period, Dál Riata extended its control to the area of Antrim closest to Argyll, much as the Lords of the Fsles were to do in the later medieval period, and this area also became known as Dál Riata. During the Middle Irish period, when claims of the Irish ancestry of Scottish royalty were being elaborated, a process of 'reverse engineering' was used by Irish writers to explain the existence of an Irish Dál Riata as the progenitor of Scottish Dál Riata rather than vice versa.

In conclusion, the Irish migration hypothesis seems to be a classic case of long-held his-

\footnotetext{
References

ALCOCK, L. 1970. Was there an Irish-Sea Culture-Province in The Dark Ages?, in D. Moore (od.), The Irish Sea Province in archaeology and history: 55-65. Cardiff: Cambrian Archaeological Association.

BAILLIE, M.G.L. 1985. Irish dendrochronology and radiocarbon dating, Ulster journal of Archaeology 48: 11-23.

BANNERMAN, J. 1974. Studies in the history of Dalriada. Edinburgh: Scottish Academic Press.
}

torical beliefs influencing not only the interpretation of documentary sources themselves, but the subsequent invasion paradigm being accepted uncritically in the related disciplines of archaeology and linguistics. The paradigm has been supported by a series of mutually sustaining positions where archaeologists have looked to the historical/linguistic model, historians have been supported by linguists, and the linguists by the historians. There are clear parallels here to the situation recently reviewed by Patrick Sims-Williams (1998) exploring the relationship of paradigm acceptance between geneticists, linguists and historians, and Forsyth (1997) in her demonstration of how linguists were driven by outmoded archaeological thought in the question of the origins of the Pictish language. I believe that none of the evidence is capable of supporting the traditional explanations, and that closer dialogue between historians, linguists and archaeologists can lead to a better understanding of the construction of identity and processes of social change in the early medieval period. The work of Forsyth (1997) and Taylor (1994) on Pictland, and Smith (forthcoming) on Brittany are signs that this is already happening. Surely the question that is of interest here is not 'where did people come from?', but 'how did people establish and change their personal and group identity by manipulating oral, literary and material culture?'. Indeed, merely by re-labelling the supposed 'Irish settlers' as 'Gaelic speakers', following the practice of contemporary writers such as Adomnán, the whole issue can be studied in an atmosphere free from the colonialist implications which have distorted the study of early medieval western Britain.

Acknowledgements. The ideas in this paper have been presented in various seminars over the last two years, and I would like to thank Dauvit Broun, Thomas Clancy, Steve Driscoll, Katherine Forsyth, Siân Jones, Robert Ó Maolalaigh, Simon Taylor,and Alex Woolf for stimulating and helpful discussion, without implicating them in the ideas put forward here.

BARBer, I.W. \& B.A. Crone. 1993. Crannogs; a diminishing resource? A survey of the crannogs of southwest Scotland and excavations at Buiston Crannog, Antiquity 67: 520-33

BRADLEY, J. 1993. Moynagh Lough: an Insular workshop of the Second Quarter of the 8th Century, in Spearman \& Higgitt (ed.): 74-81.

Broun, D. 1999. The Irish identity of the Kingdom of the Scots. Woodbridge: Boydell Press. 
BYRNE, F.J. 1973. Irish Kings and High-kings. London: Batsford. CAMPBELL, E. 1996. Trade in the Dark Age West: a peripheral activity?, in B. Grawford (ed.), Scotland in Dark Age Britain: 79-91. Aberdeen: Scottish Cultural Press.

1999. Saints and Sea-kings: the first kingdom of the Scots. Edinburgh: Cannongate/Historic Scotland.

Colgrave, B. \& R.A.B. MYNors (ed.). 1969. Bede's Ecclesiastical history of the English People. Oxford: Clarendon Press.

CRONE, A. 2000. The history of a Scottish Lowland crannog: Excavations at Buiston, Ayrshire, 1989-90. Edinburgh: STAR.

Cunluffe, B. 1979. The Celtic World. New York (NY): McGraw Hill.

DUFFY, S. 2000. Ireland and Scotland, 1014-1169: contacts and caveats, in A. Smyth (ed.) Seanchas: Studies in early medieval lrish archaeology, history and literature in honour of Francis J. Byrne: 348-56. Dublin: Four Courts Press.

DumvilLE, D. 1993. Saint Patrick and the Christianisation of Dál Riata, in D. Dumville (ed.), Saint Patrick, AD 4931993: 183-9. Woodbridge: Boydell Press.

EVANS, R.J. 1999. In defence of history, London: Granta

FERGUSON, W. 1998. The identity of the Scottish nation: an historic quest. Edinburgh: Edinburgh University Press.

FORSYTH, K. 1997. Language in Pictland: the case against nonIndo-European Pictish. Utrechl: de Keltische Draak/ Münster: Nodus Publikationen.

Foster, S. 1996. Picts, Gaels and Scots. Edinburgh: Historic Scotland.

Grabowski, K. \& D. DumvilLe. 1984. Annals of medieval Ireland and Wales: The Clonmannoise-group texts. Woodbridge: Boydell Press.

HENDERSON, J. 2000. Shared traditions? The drystone settlement records of Atlantic Scotland and Ireland $700 \mathrm{BC}-$ $\mathrm{AD} 200$, in J. Henderson (ed.), The prehistory and early history of Atlantic Europe: 117-54. Oxford: British Archaeological Reports. International series 861.

HERBERT, M. 2000. Rí Érenn, Rí Alban: kingship and identity in the ninth and tenth centuries, in S. Taylor (ed.), Kings, clerics and chronicles in Scotland 500-1297: 62-72. Dublin: Four Courts.

KILBRIDE-JONES, H.E. 1980. Zoomorphic pennanular brooches. London: Thames \& Hudson.

LAING, L. 1975. The archaeology of late Celtic Britain and Ireland $c$ 400-1200 AD. London: Methuen.

LANE, A. \& E. CAMPBELL. 2000. Excavations at Dunadd: an early Dalriadic capital. Oxford: Oxbow.

LYNN, C. 1983. Some 'early' ring-forts and crannogs, Journal of Irish Archaeology 1: 47-62.

MACALISTER, R.A.S. 1945, 1949 Corpus inscriptionum insularum Celticarum. Dublin: Stationery Office.
Nicolaisen, W.F.H. 1976. Scottish place-names. London: Batsford.

NIEKE, M. 1993. Pennanular and related brooches : secular ornament or symbol in action?, in Spearman \& Higgitt (ed.): $135-42$

Ó Cróinín. D. 1995. Early medieval Ireland 400-1200. London: Longmans.

Ó FlórnN, R. Forthcoming. Artefacts in context: personal ornament in early medieval Britain and Ireland, Proceedings of the Fourth International Conference on Insular Art. Cardiff.

O' RAHILLY, T.F. 1932. Irish dialects past and present with chapters on Scottish and Manx. Dublin: Brown \& Nolan.

RAHTZ, P.A. 1976. Irish settlements in Somerset, Proceedings of the Royal Irish Academy 76C: 223-30.

RCAHMS. 1988. Argyll: an inventory of the ancient monuments 6: Mid-Argyll. Edinburgh: HMSO.

RICHARDS, M. 1960. Irish Settlements in southwest Wales, a topographical approach, Journal of the Royal Society of Antiquaries of Ireland 90: 133-62.

RiveT, A.L.F. \& C. SMITH. 1979. The place-names of Roman Britain. London: Batsford.

SHARPE, R. (ed. \& trans.). 1995. Adomnán of Iona. Life of St Columba. London: Penguin.

Sims-Williams, P. 1998. Genetics, linguistics, and prehistory: thinking big and thinking straight, Antiquity 72: 505-27.

SMTTH, J. Forthcoming. Confronting identities: the rhetoric and reality of a Carolingian frontier, in W. Pohl \& $\mathrm{M}$. Diesenberger (ed.), Integration und Herrschaft. Ethnische Identitäten und kulturelle Muster im frühen Mittlealter. Vienna.

SPEARMAN, R.M. \& J. HIGGITT (ed.). 1993. The age of migrating ideas. Early Medieval art in Northern Britain and Ireland. Edinburgh: National Museums of Scotland/Stroud: Alan Sutton.

Stout, M. 1997. The Irish ring-fort. Dublin: Four Courts Press.

TAYLOR, S. 1994. Some early Scottish place-names and Queen Margaret, Scottish Language 13: 1-17.

(Ed.). 2000. Kings, clerics and chronicles in Scotland 500 1297. Dublin: Four Courts Press.

THOMAs, C. 1968. Grass-marked pottery in Cornwall, in J.M. Coles \& D.D.A. Simpson (ed.), Studies in Ancient Europe: 311-32. Leicester: Leicester University Press.

1973. Irish colonists in South West Britain, World Archaeology 5: 5-13.

Toner, G. 2000. Identifying Ptolemy's Irish places and tribes, in D.N. Parsons \& P. Sims-Williams (ed.), Ptolemy. Towards a linguistic atlas of the earliest Celtic place-names of Europe: 73-82. Aberstwyth: Centre for Medieval Celtic Studies. 